\title{
SESJE I KONFERENCJE NAUKOWE
}

\section{Sprawozdania}

\section{Międzynarodowy Kongres Historyków Wychowania w Am- sterdamie (10 - 14.VIII.1994)}

Education and Cultur Transfer, 1500-1994 - to temat XVI międzynarodowego kongresu historyków wychowania, który odbył się w Amsterdamie w Holandii. Zwołany on został przez International Standing Conference for the History of Education (ISCHE).

Gościny dla przeprowadzenia obrad udzielił kongresowi cały campus Wolnego Uniwersytetu (Vrije Universiteit), położony w południowej części miasta.

Glówny temat przewijał się przez sesje plenarne i powołane kongresowe sekcje tematyczne oraz stałe grupy robocze działające przy ISCHE. Obradowały także zespoły okrągłego stołu - nowa forma pracy kongresu.

Obrady plenarne obejmowały referaty wprowadzające w problematykę kongresu. Wygłosili je min. Shulamith Shahar (Izrael), Harvey Siegel (USA), Richard Aldrich (W. Brytania), André Cherval (Francja), Peter Selten (Holandia), Walter Hornstein (RFN), Linda Pollock (USA), Willem Frijhoff (Holandia).

Działały cztery kongresowe sekcje tematyczne, które skupiały się na uszczególowieniu następujących problemów: Cultural transfer, the educational system and national, regional or local authorities (political, religious, social); Cultural transfer and child rearing within the family; Cultur transfer and the subcultures of young people; Means and cultural transfer (books, pictures, oral traditions, pedagogical relations, teaching methods, rituals).

Obradowały także dwie stale grupy robocze ISCHE. Pierwsza zajmująca się dziejami wychowania przedszkolnego i druga - badająca historię edukacji dziewcząt.

Zgłoszono ponad 150 referatów. Stąd też sekcje podzielono na mniejsze zespoły, które obradowały paralelnie. Inaczej nie udałoby się pomieścić obrad w czasie tradycyjnych czterech niepelnych dni. Obrady zwykle zaczynają się pierwszego dnia w godzinach popołudniowych oraz kończą czwartego dnia lunchem.

W kongresie wzięło udzial ponad 150 uczonych ze wszystkich kontynentów. Reprezentowali oni następujące państwa: Australię, Belgię, Brazylię, Czechy, Danię, Finlandię, Francję, Hiszpanię, Holandię, Iran, Irlandię, Izrael, Japonię, Kanadę, Meksyk, Niemcy, Norwegię, Polskę, Południową Afryke, Portugalię, Rosję, Rumunię, Szkocję, Szwajcarię, Szwecję, USA, Węgry, Wielką Brytanię (w tym Hongkong).

Analizując pobieżnie sposób referowania problematyki będącej przedmiotem obrad a także niektóre jej treści, można było odnieść wrażenie, że nie mieszczą się one w tematyce kongresu, że zbyt ewidentnie grawitują ku zagadnieniom współczesnym, że są to raczej rozważania socjologiczne, a nie historyczne, czy historyczno-pedagogiczne.

W trakcie obrad można było dostrzec ważną przesłankę metodologiczną, jaka zarysowała się podczas dyskusji. Dotyczy ona związków i to bardzo ścisłych pomiędzy historią a socjologią, 
pomiędzy historią wychowania a socjologią wychowania Jak zresztą od dawna zauważają niektórzy metodologowie historii „różnic w przedmiocie między historią i socjologią nie ma, bowiem obie te nauki zajmują się badaniem społeczeństwa ludzkiego"'. Odmienność tkwi w czasokresie, w jakim te nauki społeczeństwo ludzkie analizują. Historia interesuje się przeszloścį̧ podczas gdy socjologia - współczesnością. Refleksje podejmowane w tym kontekście w czasie obrad coraz bardziej wskazywały na to, iż społeczna historia wychowania ${ }^{2}$ znajduje coraz większe uznanie wśród badaczy i że coraz większa liczba uczonych stosuje w swych badaniach zasadę historyzmu rozumianą tu jako uwzględnianie w rozważaniach o czlowieku i życiu społecznym kontekstu historycznego z jednej strony, z drugiej zaś na wykorzystywanie przez historyków, w tym i historyków wychowania osiągnięć zarówno teoretycznej, jak i praktycznej socjologii ( $w$ tym i socjologii wychowania) jako ważnej i poważanej bazy wiedzy pozaźródlowej.

Przedmiotem szczególnego zainteresowania stała się nowa forma wymiany myśli naukowej wprowadzona przez ISCHE - round table. Podczas XVI Kongresu odbyły się dwie dyskusje okraglego stolu: Gender perspectives in the history of education oraz The history of education in the former communist world. Zwłaszcza ten drugi temat, jak można się było spodziewać, wywołał wielkie zainteresowanie. Przybyła duża liczba uczestników.

W kongresie amsterdamskim uczestniczyli także bardzo aktywnie Polacy. Przygotowali oni następujące referaty: prof. dr hab. Lech Mokrzecki i dr Józef Žerko (Uniwersytet Gdański) - referat wspólny pt. The influences of international exchanges on learning and education in Poland: 16 th throught 18 th centuries; prof. dr hab. Eleonora Sapia-Drewniak (Uniwersytet w Opolu) na temat: Mother's contribution to the family cultur transmission on the Polish-German borderland in the period between the two World Wars; prof. dr hab. Danuta Koźmian (Uniwersytet Szczeciński) pt. Regionalismus und sein Einfluss auf die Erziehung in den pädagogischen Meinungen von Aleksander Patkowski in der Zweiten Republik Polens, 1918 -1939; prof. dr hab. Jan Hellwig (UAM - Poznani) nt. Kulturkampf auf die durch Preussen annektierten polnischen Gebieten im XIX und am Anfang des XX Jahrhundert; prof. dr hab. Bogusław Chmielowski (AWF - Katowice) nt. Le transfert de la culture à l'école à l'époque de la Pologne Populaire (1944-1989).

Wystąpienia polskie, jak zwykle, przyjęte były z dużym zainteresowaniem i uznaniem. Wywołały liczne pytania i dyskusje trwające również po zakończeniu obrad. Spowodowały także zaproszenia do wspólnych prac badawczych, wizyt naukowych, wymiany informacji naukowej, literatury, udziału w kolokwiach i sesjach naukowych. Ze strony polskiej w obradach uczestniczył także prof. dr hab. Czesław Majorek (WSP - Kraków), który do czasu XVI kongresu był czlonkiem Zarządu ISCHE - wybranym, po przerwie po raz drugi, na XIII kongresie w Zurichu (1991 r.).

Sprawy organizacyjne na kongresie amsterdamskim poświęcone były zmianom w statucie, regulaminowym wyborom nowych władz, wydawaniu organu ISCHE - International Newsletter for the History of Education. Nowym prezydentem zostal prof. Richard Aldrich (W. Brytania), a do egzekutywy (zarządu) weszli James C. Albisetti (USA), Antonio Vinao Frengo (Hiszpania) i Glenn Smith (USA).

Jan Hellwig

\section{Konferencja naukowa: „Teoretyczne i praktyczne oferty edukacyj- ne we wspólczesnej pedagogice i ich źródla historyczne"}

W dniach 26 i 27 IX 1994 r. odbyla się w Katowicach konferencja naukowa zorganizowana przez Katedrę Podstaw Pedagogiki i Historii Wychowania Uniwersytetu Śląskiego na ww. temat. Celem konferencji było dokonanie przeglądu wspólczesnych, teoretycznych i praktycznych koncepcji edukacyjnych oraz wskazanie ich historycznych źródeł.

I J. Topolski, Metodologia historii. Warszewa 1973, ss. 590-591.

2 J. Dybiec, Cz Majorek, Kspólczesna koncepcja historii wychowania jako nauki. "Rozprawy z Dzjejów Ośwjaty" 1989 , T. XXXII, ss. 141 - 154; J. Hellwig, Z dziejów historii wychowania i jej teorii w Polsce. „K wartalnik Pedagogiczny” 1992 , nr 1, ss. 82 - 103. 